\title{
Ecological Postulates of the National Environmental Policy (on the Example of the Russian Federation)
}

\author{
Svetlana Kurbatova $^{1 *}$, Larisa Aisner ${ }^{1}$, Alexey Rusakov ${ }^{1}$, and Valentina Naumkina ${ }^{2}$ \\ ${ }^{1}$ Krasnoyarsk state agrarian University, Kommunisticheskaya St, Krasnoyarsk, 49, 662150, Russia \\ ${ }^{2}$ Professor, Dr. of science in Law, law Institute, Katanov Khakass State University, prosp. Lenina,90, \\ Abakan, 655000, Russia
}

\begin{abstract}
The article, using the example of the Russian Federation, considers a number of environmental postulates that the authors consider to be the necessary condition and at the same time content for the successful implementation of the national environmental policy. The authors investigate the high-quality environmental law; effective working mechanisms for monitoring and supervising its compliance; and the inevitability of legal liability for violation of environmental legal norms.
\end{abstract}

\section{Introduction}

Environmental problems have been relevant since the middle of the previous century, when many countries, Russia including, entered the stage of industrialization. Consumer attitude to nature in the pursuit of minerals, urbanization of territories, development of new areas, etc. became the root cause of the environmental problems, first on a national and then on a global scale.

At present, awareness of the consequences of such a destructive anthropogenic impact on nature has come. And the problem as such is not solved yet, it has only worsened over time and acquired new forms and scales.

This issue is particularly relevant for Russia, as it is one of the main countries with the most polluted environment: deforestation, soil, water, and air pollution have become urgent across the geographic spectrum.

The problem of air pollution has become particularly relevant. In recent decades, it has worsened due to the expansion of industrial centers. In regions with high population density, developed industrial production and congestion of vehicles, the level of air pollution is particularly high. Harmful substances pollute and destroy the ozone layer, causing acid precipitation. The lack of measures to reduce emissions into the atmosphere leads to negative consequences for humanity.

It is a paradox, but among the cities of Russia that are considered dangerous to live in, Siberian cities take the lead. Repeatedly, the first place in the world ranking of pollution was occupied by the center of the Krasnoyarsk territory - Krasnoyarsk, the largest

*Corresponding author: sveta_kurbatova@mail.ru 
industrial center of Russia with difficult environmental situation. Every year, the level of air pollution in the city increases. For this reason, there is a frightening increase in the number of cancer patients. Arctic Norilsk and coal-mining Achinsk (also cities in the Krasnoyarsk territory) are regularly among the three most polluted cities in Russia, although, for example, one of the sources of emissions, Nickel plant that had emitted hundreds of tons of sulfur dioxide into the atmosphere every year, was closed in 2016.

In general, it is noted that in many parameters of emissions into the atmosphere, Russia is ahead of most countries of the European Union and neighboring countries: the quantity of substances polluting Russian air has recently either increased or practically not decreased, while in other countries the situation is reversed-emissions in most cases are reduced. For example, when comparing these countries with changes in emissions of nitrogen oxides and volatile organic compounds that have occurred over the past five years, it is clear that only Russia has increased emissions for both indicators.

During the period from 2002 to 2016/2017, specific emissions of nitrogen dioxide and VOCS (per person and per US dollar of GDP) from all sources to the atmosphere in Russia increased, while the vast majority of countries in the European Union, the OECD, China, Belarus and Kazakhstan did not increase in both parameters. In 2004-2016/2017, the reduction of sulphur oxide emissions from stationary sources was significantly faster in China and Belarus than in Russia: the share of reduced emissions is four and three times higher, respectively. During the period 2016/2017 emissions of sulfur oxide and nitrogen oxide per US dollar from stationary sources in Russia were 7-30 times higher than in Germany, and 1.15-3 times higher than in Turkey and China. In the US, this figure is 6-20 times lower than in Russia. Of these countries, only in Turkey the specific emissions of sulfur oxide per person are higher than in Russia.

In October 2019, the Russian branch of Greenpeace conducted a survey on what people think and know about air quality. More than 12,000 people took part in it within two weeks, and almost all of them (93\%) are dissatisfied with the way they are informed about air quality. At the same time, the problem remains relevant: $37 \%$ of respondents constantly feel air pollution, and $25 \%$ - several times a week. $35 \%$ of respondents do not know where to look for data, and $89 \%$ evaluate the situation with the environment subjectively, focusing on the smell, the presence of smoke and dust in the air and their own health.

The preservation and restoration of environment is one of the main tasks of each state. One of the ways to solve environmental problems in general, and to directly solve the problem of air pollution, we see in the specific state of three environmental postulates:

1) the appropriate regulatory framework (international and national level), since it is in the regulatory legal acts that the limits of proper behavior of participants in relations that affect the environment and their legal status should be prescribed,

2) strict control over its compliance, otherwise it loses the meaning of having the most remarkable laws;

3) the inevitability of legal liability for its violation, provided that the penalties are serious and proportionate, since the clear understanding of the consequences for violation of legal norms, with the understanding that punishment is a reality, and not an empty threat, is an effective incentive to comply with the existing regulations.

However, in Russia, this mechanism is in an unsatisfactory state.

\section{Methodology}

Methodology of research are theoretical foundations, which include both original empirical and the theoretical data within the framework of the issues; scientific and methodological basis, which includes the scientific-methodical apparatus (part of the theory in the arsenal 
of procedural knowledge, which basic elements are the methods, techniques, technology, tasks) and methodological framework (integrate into the composition methods of scientific justification for the specific elements of scientific methodology and justification). The basic methods for the research are: analysis, which is used to identify individual elements and their features within the affected topic; descriptive method, which includes methods of interpretation, comparison, generalization; statistical method for collecting and studying quantitative data; synthesis and deduction, which are used to generalize the results obtained and draw appropriate conclusions.

\section{Environmental postulates in the Russian Federation: content and implementation}

To successfully implement and achieve the better results in a specific area of state policy, in this case, in the field of ecology, it is necessary that the triad of environmental postulates, which we have outlined above, be implemented at the national level. The content of which, as well as their implementation in Russia, will be discussed below.

First, the state should form a serious legislative framework based on a systematic approach aimed at a comprehensive settlement of relations in the field of ecology, in unity with a number of branches of law: environmental, international, administrative, tax, budgetary, civil, criminal, etc. While the basis for the formation of the national legal framework is provided by the international base. For example, Russia participates in the 1979 Geneva Convention On long-range transboundary air pollution and the 1985 Vienna Convention «On the protection of the ozone layer» and the Montreal Protocol on substances that Deplete the ozone layer, the 2001 Stockholm Convention on persistent organic pollutants, etc. [1].

There is a whole package of normative legal acts at the national level: the Federal law «On environmental protection», Decree of the President of the Russian Federation dated 30.04.2012 «Fundamentals of the state policy in the field of environmental development of the Russian Federation until 2030» [2], Resolution of the government of the Russian Federation dated 15.04.2014 №. 326 «On approval of the state program of the Russian Federation "environmental protection» [3] and others.

However, there are many questions about the quality of the legal environmental regulations and the content of the environmental legislation, namely:

- There is a problem of division of powers between Federal public authorities and public authorities of subjects of the Russian Federation. There are practically no specific mechanisms for delineating the powers of the Russian Federation and its subjects, not only in the field of nature management and environmental protection, but in the field of ensuring environmental safety and procedures for implementing these powers as well [4]

- The specifics of nature as an object of property are not taken into account. The legal regime for this special object must be special, different from the regime for material objects of the economic and social environment. Theoretically, it should be such that, while satisfying a certain optimal amount of human needs, nature should be preserved. [5]

- often normative legal acts are used as an element of the mechanism for hiding information about the real environmental situation in Russia, and such a state of affairs causes particular concern due to the fact that those legal acts come from the state, which raises certain questions.

Thus, it is noted that during the period from 1992 to 2017 the MPC values for some pollutants in the air in Russia were repeatedly and significantly changed. Almost every change increased the MPC, there were cases of reducing the hazard class. The chronology of changes in the MPC for the most common substances that were often used to determine the API (total air pollution index) is shown in table 1 . 
Table 1. Changes in the regulations that establish the maximum permissible coefficient (MPC) of atmospheric air in populated areas for the most common pollutants*

\begin{tabular}{|c|c|c|c|c|c|}
\hline $\begin{array}{c}\text { Year } \\
\text { of } \\
\text { change }\end{array}$ & Substance & Indicator & $\begin{array}{l}\text { Before } \\
\text { the } \\
\text { change }\end{array}$ & $\begin{array}{l}\text { After } \\
\text { the } \\
\text { change }\end{array}$ & $\begin{array}{l}\text { How much has } \\
\text { changed }\end{array}$ \\
\hline \multirow[t]{2}{*}{1999} & \multirow[t]{2}{*}{$\begin{array}{l}\text { Methylmercaptan } \\
\text { (methanethiol) }\end{array}$} & $\begin{array}{l}\text { MPC M. R. } \\
\text { (mg/cubic m) }\end{array}$ & $9 * 10-6$ & 0.0001 & $\begin{array}{l}\text { Increase by } 11 \\
\text { times }\end{array}$ \\
\hline & & $\begin{array}{l}\text { Toxicity } \\
\text { class }\end{array}$ & 2 & 4 & $\begin{array}{l}\text { Reduction by } 2 \\
\text { classes }\end{array}$ \\
\hline \multirow[t]{2}{*}{2006} & \multirow[t]{2}{*}{ Nitrogen dioxide } & $\begin{array}{l}\text { MPC M. R. } \\
(\mathrm{mg} / \text { cubic } \mathrm{m})\end{array}$ & 0.085 & 0.2 & $\begin{array}{l}\text { Increase by } 2.4 \\
\text { times }\end{array}$ \\
\hline & & $\begin{array}{l}\text { Toxicity } \\
\text { class }\end{array}$ & 2 & 3 & $\begin{array}{l}\text { Reduction by } \\
\text { one class }\end{array}$ \\
\hline 2006 & $\begin{array}{l}\text { Methylmercaptan } \\
\text { (methanethiol) }\end{array}$ & $\begin{array}{l}\text { MPC M. R. } \\
\text { (mg/cubic m) }\end{array}$ & 0.0001 & 0.001 & $\begin{array}{ll}\text { Increase by } 10 \\
\text { times }\end{array}$ \\
\hline 2008 & $\begin{array}{l}\text { Methylmercaptan } \\
\text { (methanethiol) }\end{array}$ & $\begin{array}{l}\text { MPC M. R. } \\
(\mathrm{mg} / \text { cubic } \mathrm{m})\end{array}$ & 0.001 & 0.006 & $\begin{array}{lll}\text { Increase by } & 6 \\
\text { times } & & \\
\end{array}$ \\
\hline \multirow[t]{3}{*}{2014} & \multirow[t]{3}{*}{ Formaldehyde } & $\begin{array}{l}\text { MPC M. R. } \\
\text { (mg/cubic m) }\end{array}$ & 0.035 & 0.05 & $\begin{array}{l}\text { Increase by } 1.4 \\
\text { times }\end{array}$ \\
\hline & & $\begin{array}{l}\text { MPC M. R. } \\
(\mathrm{mg} / \text { cubic } \mathrm{m})\end{array}$ & 0.003 & 0.01 & $\begin{array}{l}\text { An increase of } \\
3.3\end{array}$ \\
\hline & & $\begin{array}{l}\text { Toxicity } \\
\text { class }\end{array}$ & 2 & 1 & $\begin{array}{lll}\begin{array}{l}\text { Increase by } \\
\text { class }\end{array} & & \\
\end{array}$ \\
\hline 2014 & Formaldehyde & $\begin{array}{l}\text { Toxicity } \\
\text { class }\end{array}$ & 1 & 2 & $\begin{array}{lr}\begin{array}{l}\text { Reduction } \\
\text { one }\end{array} & \text { by } \\
\text { (return) } & \text { class } \\
\end{array}$ \\
\hline 2015 & Phenol & $\begin{array}{l}\text { MPC M. R. } \\
(\mathrm{mg} / \text { cubic m) }\end{array}$ & 0.003 & 0.006 & $\begin{array}{l}\text { Increase by } 2 \\
\text { times }\end{array}$ \\
\hline 2017 & Phenol & $\begin{array}{l}\text { MPC M. R. } \\
\text { (mg/cubic m) }\end{array}$ & 0.006 & 0.01 & $\begin{array}{l}\text { Increase by } 1.67 \\
\text { times }\end{array}$ \\
\hline 2017 & Nitrogen dioxide & $\begin{array}{l}\text { MPC M. R. } \\
\text { (mg/cubic m) }\end{array}$ & 0.085 & 0.2 & $\begin{array}{l}\text { Increase by } 2.35 \\
\text { times }\end{array}$ \\
\hline
\end{tabular}

* Compiled according GN2.1.6.695-98, GN2.1.6.789-99, GN2.1.6.1983-05, GN2.1.6.2326-08, GN2.1.6.1338-03, the resolution of the Chief state sanitary doctor dated April 7, 2014 No. 27 the Decision of the Chief state sanitary doctor dated 17 June 2014 №37, the resolution of the Chief state sanitary doctor dated 12 January 2015, No. 3, GN2.1.6.3492-17.

The MPC for other substances was also changed, for example, by the resolution No. 37 of the Chief state sanitary doctor of the Russian Federation dated May 31, 2018 [6].

In this regard, many data on the reduction of pollution in Russia do not relate to real changes, but to changes in the MPC values. For example, over the past 19 years (from 1999 to 2017), the MPC of methyl mercaptan-an extremely unpleasant-smelling substance increased by 660 times (and over the past 10 years - 60 times).

E. I. Mayorova calls the main problem of environmental legislation its corruption, using this term, she makes a start from the concept of corruption-related factors, specified by the Federal law dated 17.07.2009 №. 172-FZ «On anti-corruption examination of normative legal acts», which include one or more elements that may later appear as corruption in certain circumstances.

The second element of the above-mentioned triad of environmental postulates that are mandatory for the implementation of state environmental policy, including in the Russian Federation, is the presence of an effective mechanism for monitoring compliance with 
environmental legislation. First, this applies to the work of Executive authorities, controlling and supervising bodies. On the other hand, it is also about attracting members of the public and creating open access to materials of environmental significance. Therefore, in October 2019 the presidential Council for civil society development and human rights held a working meeting on the problem of air quality regulation. The event was attended by representatives of relevant departments, the scientific community and public organizations. As a result of the discussion, most of the participants of the meeting came to the conclusion that it was necessary to fully open the materials (including research) on the basis of which the maximum permissible concentrations (MPC) of harmful substances in the atmospheric air were set and changed. In addition, according to the participants of the meeting, it is necessary to analyze and open discussion of existing standards (primarily for carcinogenic substances), which should involve members of the public. It is also necessary for the effective implementation of the national projects "health" and "Ecology".

Environmental control (supervision) as the most important legal measure to ensure rational use of natural resources and environmental protection performs a number of functions - preventive, informational and punitive. Back in 2012, within the framework of the discussion on December 17, 2012 held by the state Duma Committee on natural resources, environmental management and ecology and dedicated to topical issues of environmental control (supervision) in Russia [7].

The reasons for the inefficiency of state environmental supervision were highlighted and the problems were voiced. So, the main reasons for its inefficiency are:

- orientation of criteria for the effectiveness of control and supervision activities in the field of environmental protection to identify environmental violations and not to prevent them. Such state environmental supervision is aimed not at the result, but at the statistics of offenses, building the "rod" system.

- the desire to replenish the budget through fines for violations of environmental requirements, compensation for damage caused to the environment, etc.;

- high level of corruption in the implementation of environmental control (supervision);

- fourth, the weak development of other environmental instruments. Thus, in the legislation of a number of foreign countries, environmental control (supervision) has a broader content than the direct activity of authorized entities to identify and suppress environmental offenses. The effectiveness of the environmental control (supervision) mechanism is ensured only through interaction with other environmental instruments, such as environmental expertise, payment for negative impact on the environment, accounting for objects of economic and other activities, environmental monitoring, environmental regulation, legal liability for environmental offenses, compensation for damage caused to the environment, etc.

- almost all separate areas of state environmental control (supervision), such as state land supervision, state water supervision, and state forest supervision, have separate regulations that do not correlate with the regulations on the procedure for implementing state environmental supervision.

- a broad understanding of environmental control in relation to state environmental supervision is not consistent with the competence of state authorities to carry out various types of environmental control (supervision), since, for example, only Federal Executive authorities (the Federal service for state registration, cadastre and cartography) have the authority to carry out state land supervision.

- interaction of state bodies in the implementation of state environmental supervision is poorly developed.

- "bad" environmental pollution statistics that do not reflect the actual state of the environment.

However, up to date, the situation has not changed. 
The third environmental postulate-the inevitability of legal liability for violation of environmental legislation, provided that the penalties are serious and proportionate, is also not implemented in Russia:

- there are gaps in the legislation, as well as the lack of relevant documents of legal significance often lead to the fact that persons "go away" from responsibility. For example, only persons who illegally move goods worth more than 1.5 million rubles across the Russian customs border can be held criminally liable. However, it is not possible to determine the real value of flora and fauna objects, as well as their derivatives, due to the lack of the legal market for their sale. Therefore, the detained shipments of these goods are usually estimated at tens or hundreds of times lower than their value on the "black market" in the countries of the Asia-Pacific region.

- at the Federal and regional levels of legislation, there are practically no means of combating corruption in the sphere of ecology and nature management, despite the fact that its objects have a very high economic value [8].

- in the code of administrative offences in Chapter 8. «Administrative offenses in the field of environmental protection and natural resource management» the amount of fines is very small for the absolute majority of offenses.

- criminal punishment is also not serious, given the damage that environmental crimes carry (and not only material but also social, moral, physical, given that the negative impact on the environment suffering as a result of society in General), it is necessary to increase penalties and to tighten other types of criminal penalties stipulated by the sanctions of the relevant articles of the Special part of the Criminal code of the Russian Federation.

It should be noted that the main pollutants of the environment are industry and the economic activities of large enterprises. In comparison, the share of private individuals involved in pollution is quite small. The fact that enterprises are the main polluters of the environment creates difficulties in determining the subjective and objective features of the corpus delicti of an environmental crime. Problems arise when determining whether there is a common causal link, since the damage is caused due to multiple factors; determining the amount of damage caused; establishing a specific natural object that has been harmed, since the damage is done to several objects at once, that is, in a complex way. In addition, it is difficult to establish the guilt, since the principle of guilt and personal responsibility does not apply in collective decision-making. Blame is shifted to the team and personal responsibility is «blurred». A solution to this problem is the introduction of a «legal entity» in the category of the subject of crime for environmental criminal acts.

\section{Conclusions}

1. Taking into account that over the past 20 years (1999-2017), the state authorities of the Russian Federation significantly increased the MPC of several common pollutants in the absence of justifications for these increases in open sources, Russian ecological situation and, in particular, air pollution, requires a serious re-evaluation and rethinking. After all, even with this state policy, the environmental situation in Russia is recognized as one of the most dangerous in the world. Changing the MPC rules has led to improvements in the environment in many localities, but only on paper. The actual situation with pollution has not actually improved, but on the contrary, has worsened: for example, formaldehyde emissions in 2017, that is, in the three years since the change in standards in 2014, increased by more than a third.

2. In a number of cities, due to such a change in the MPC rules, the grounds for financing environmental measures by business and the state have disappeared. In particular, it affected 46 cities in Russia, where the average annual concentrations of formaldehyde in 2017 exceeded the "old" MPC, but were lower than the "new" ones. 
3. It is necessary to systematize environmental legislation by refining the content of many existing regulations, eliminating conflicts and duplications, and filling in existing gaps. It should result in the adoption of the Environmental code of the Russian Federation, which would include a General part (principles, sources, conceptual framework, etc.), particular (containing some of the institutions of environmental law: regulation, protection and use of lands, waters, air, mineral resources, forests, wildlife, protected natural areas) and Special (consolidating the basic principles of international legal protection of the environment, characteristics of the objects included in the international legal environment, the main provisions of international responsibility for environmental offenses).

4. It is necessary to support the ideas laid down in the appeal of the Russian branch of Greenpeace to the Government of the Russian Federation in November 2019 about the need to take certain measures to correct the situation, namely:

- install fixed monitoring stations or upgrade existing ones for continuous automatic monitoring of air pollution in all industrial centers and cities with a population of more than 100,000 thousand people.

- eliminate duplication of powers to provide information about the quality of atmospheric air to the population among the authorized bodies and assign this function to one state body.

- create an electronic resource that provides data on air quality, taking into account the risk assessment for human health, where data from all automatic air control stations available in localities will stream relevant near-real-time data. In case of increasing concentration of pollutants, ensure prompt response in order to minimize harmful effects on public health.

5. there should be real control and supervision over the entities that carry out industrial activities in order to ensure that they comply with the requirements of environmental legislation. At the same time, the focus of the criteria for the effectiveness of control and supervision activities in the field of environmental protection should be on the prevention of environmental offenses, not on their detection.

6. increasing the scope of public control, including through the introduction of the system of open access of materials (including research), on the basis of which the maximum permissible concentrations (MPC) of harmful substances in the air are set and changed, as well as involving members of the public in open discussions of existing standards (primarily for carcinogenic substances).

7. it is necessary to seriously review the issues related to administrative and criminal liability for violation of environmental legislation (types of corpus delicti and punishment, the subject of crimes, the possibility of conditional early discharge, the use of mitigating circumstances in the absence of aggravating ones, of an environmental nature, etc.).

There are also many other problems both theoretical and practical relating the content of the postulates under consideration and their implementation. All this indicates the seriousness of the problem and the need for its early resolution, which, however, should not affect the quality of this process.

\section{References}

1. International treaties and agreements with the participation of the Ministry of natural resources of the Russian Federation http://www.mnr.gov.ru/activity/international_agreements/

2. Decree of the President of the Russian Federation dated 30.04.2012 «Fundamentals of the state policy in the field of environmental development of the Russian Federation until 2030» https://base.garant.ru/70169264/ 
3. Resolution of the government of the Russian Federation dated 15.04.2014 No. 326 «On approval of the state program of the Russian Federation "environmental protection». https://base.garant.ru/70643488/

4. H. Xie, Ya. He, Yo. Choi, Q. Chen, H. Cheng Warning of negative effects of land-use changes on ecological security based on GIS. Science of the Total Environment 704 (2016). https://doi.org/10.1016/j.scitotenv.2019.135427

5. V. Mauerhofer, I. Laza, How do ecosystem services perform in enforceable law? Potentials and pitfalls within regional and national integration, Ecosystem Services 29(B), (2016). https://doi.org/10.1016/j.ecoser.2017.07.006

6. Resolution №. 37 of the Chief state sanitary doctor of the Russian Federation dated May 31, 2018. https://normativ.kontur.ru/document?moduleId=1\&documentId=315118

7. Current issues of environmental control (supervision) in the Russian Federation. https://xn----stbmju3c.xn--p1ai/a191857-aktualnye-voprosy-ekologicheskogo.html

8. M. Kalamas, M. Clevel, M. Laroche, Pro-environmental behaviors for thee but not for me: Green giants, green Gods, and external environmental locus of control, Journal of Business Research 67(2), (2016). https://doi.org/10.1016/j.jbusres.2013.03.007 